\title{
Export vs. FDI: Sandwich Sorting with Quadratic Preferences
}

\author{
Niklas Herzig
}




\title{
Export vs. FDI: Sandwich Sorting with Quadratic Preferences
}

\author{
Niklas Herzig*
}

March 2016

\begin{abstract}
By applying quadratic instead of CES consumer preferences in a monopolistic competition model with heterogeneous firms, this paper investigates the robustness of the conventional sorting of cross-border active firms, first described by Helpman, Melitz and Yeaple (2004), and finds thereby an alternative type of sorting: While (sufficiently) productive firms export and more productive ones engage in foreign direct investment (FDI), the most productive firms do not undertake FDI, but export again, establishing the so-called sandwich sorting. Evidence for this type can be observed for investment and services trade patterns.
\end{abstract}

Keywords: Quadratic preferences, heterogeneous firms, exporting, FDI, unconventional sorting.

JEL classifications: F10, F12

\section{Introduction}

How to serve a foreign market in a world with trade barriers (tariffs, transportation costs, ...) and economies of scale? Cross-border active firms choose between two mutually exclusive modes of operation regarding a foreign country: either they export products manufactured in the home country to the foreign country or they undertake foreign direct investment (FDI) in the foreign country to build up production facilities abroad. ${ }^{1,2}$ Firms involved in the latter option are called multinational enterprises (MNEs). ${ }^{3}$ Exporters and MNEs are preeminent and unique in (performance) parameters since this group of internationally engaged enterprises (often called internationalized firms (IFs)) is comprised of larger, more productive and higher value added firms which pay higher wages, use more capital per worker and employ more skilled workers relative to domestic firms. ${ }^{4}$ In line with this empirical regularity a theory going back to Helpman, Melitz

${ }^{*}$ Department of Business Administration and Economics, Bielefeld University, Universitätsstraße 25, D-33615 Bielefeld; e-mail: niklas.herzig@uni-bielefeld.de.

${ }^{1}$ Throughout the paper the term FDI is used as a synonym for horizontal FDI, i.e. the replication of production and sales structures in a foreign country with the aim to serve its market (motive/incentive: tariff/transport cost jumping/saving or market access; see for an illustrating model: Markusen (1984)), in contrast to vertical FDI, i.e. the fragmentation of production processes in form of the relocation of stages with the aim to generate benefits in serving the home market (motive/inventive: comparative advantage; see for an illustrating model: Helpman (1984)); see Antràs and Yeaple (2014) for the evolution of the theoretical foundation of FDI incentives (from the traditional international-finance approach to the modern industrial-organization approach).

${ }^{2}$ Given the cost structure assumed below firms do not have any incentive to serve a foreign market via exports and affiliates simultaneously. They always choose one of these options for their international activity in a country abroad. Beyond the bilateral setting a hybrid (and here not further considered) form of the two modes of international operation of firms is given by export-platform FDI (see for its theoretical treatment: Motta and Norman (1996), Yeaple (2003), Grossman, Helpman and Szeidl (2006) and Ekholm, Forslid and Markusen (2007) and its empirical treatment: Hanson, Mataloni and Slaughter (2005) and Baltagi, Egger and Pfaffermayr (2007)); for firms simultaneously choosing both operation modes, each for a different market, see Oberhofer and Pfaffermayr (2012).

${ }^{3}$ See Caves (2007), p. 1: A multinational enterprise is defined as "[a firm] that controls and manages production establishments - plants - located in at least two countries".

${ }^{4}$ Among a comprehensive literature regarding the performance premia of IFs see e.g. for exporters Bernard and Jensen (1995), Bernard and Wagner (1997) and Bernard, Jensen, Reding and Schott (2007), and for MNEs Doms and Jensen (1998) and Antràs and Yeaple (2014), and for both types of firms Mayer and Ottaviano (2008). An overview of the literature on firm heterogeneity and firm-level globalisation strategies is provided by Greenaway and Kneller (2007). 
and Yeaple (2004) seeks to explain differences in firms' international activity status and operation mode by firm heterogeneity, i.e. differences in firm productivity respectively marginal costs. Their theory postulates that the least productive firms exit the market and firms with low productivity restrict their activity to the domestic market, while the more productive ones also serve foreign markets via exports. Only the most productive firms sell domestically, engage in FDI in addition and become a multinational enterprise. ${ }^{5}$

The described type of allocation of (international) operation modes across firm productivity (sorting or self-selection of firms), called conventional sorting, is theoretically derived from a Melitz (2003)-style model of heterogeneous firms in monopolistic competition with constant-elasticity-ofsubstitution (CES) consumer preferences, iceberg transport costs, (fixed) market entry and operation costs and a Pareto distribution of firm productivities. It reflects the firms' solution approach to the proximity-concentration trade-off that firms face when choosing the operation mode: The local proximity of firm production to the foreign sales market, realized through FDI and assuring transport cost savings, is juxtaposed to the local concentration of production, achievable through exporting, and therefore the exploitation of economies of scale. Depending on productivity and (proportionate) sales volumes, firms attach different weights to proximity and concentration in their decision about operation modes, since a high-productivity firm with large sales is able to cover fixed costs of FDI and to generate relatively high variable cost savings due to the proximity to the sales market, overcompensating the fixed costs, while a firm with medium productivity and small profits is unable or unwilling to cover the high fixed costs of investment and reaps higher benefits from production concentration. ${ }^{6}$

The contribution of the present paper now consists of checking the robustness of the conventional sorting with respect to changes in the model setting, in particular the underlying consumer preferences. Motivated by the empirical facts that (i) the price elasticity of demand and firm markups are not constant $^{7}$ (as implied by CES preferences) and (ii) the sorting structure may be more complex, less plain and monotonic in this paper I substitute CES preferences with equally standard quadratic preferences in a monopolistic competition model with heterogeneous firms and find an alternative type of sorting, which is consistent with the meta-analysis about firm selection effects conducted by Mrázová and Neary (2011).

As indicated above, some types of international firm activity reveal patterns that differ from conventional sorting; particularly investment and services trade. Considering the firms' investment choice (between acquisition and greenfield investment) Spearot (2012) finds for North-American industrial firms between 1980 and 2004 that those in a middle range of productivity engage in the largest amount of investment, both for acquisitions and greenfield investment. For firms being active in services trade ${ }^{8}$ a robust finding suggests some sorting which is reversed to the conventional one: while the more productive firms are engaged in exports, the less productive suppliers of services undertake foreign direct investments. Bhattacharya, Patnaik and Shah (2012) find this result for the Indian software industry between 2000 and 2008 and it is also confirmed in a recent study by Foster-McGregor, Isaksson and Kaulich (2014) for several sub-Saharan African countries. Verifying the finding for a highly developed country Wagner (2014) gets for German firms in services trade the result that those with FDI are less productive than firms that export.

The remainder of the paper is organized as follows: After outlining some crucial elements of the

\footnotetext{
${ }^{5}$ Empirical evidence for a productivity premium of multinational enterprises (relative to exporters) and exporters (relative to domestic firms) is found in Kimura and Kiyota (2006) and Tomiura (2007) for Japan, Girma et al. (2005) for the UK, Wagner (2006) and Arnold and Hussinger (2010) for Germany and Engel and Procher (2012) for France.

${ }^{6}$ The "proximity-concentration trade-off" is established in the advanced literature of horizontal FDI with the work by Brainard (1997) and continued by Markusen and Venables (2000), generalizing Brainard's setting by allowing for factor endowment differences between two countries and thereby allowing for country asymmetries. By incorporating firm asymmetries (heterogeneity) Helpman, Melitz and Yeaple (2004) extend the setup in which the trade-off can be analysed and Ramondo, Rappoport and Ruhl (2013) put this model to a stochastic environment.

${ }^{7}$ Across (size-)heterogeneous markets see e.g. Barron et al. (2008), Campbell and Hopenhayn (2005) and Hummels and Klenow (2005) and across heterogeneous firms see e.g. De Loecker and Warzynski (2012) and De Loecker, Goldberg, Khandelwal and Pavcnik (2016).

${ }^{8}$ For an overview about services trade and policy see Francois and Hoekman (2010).
} 
model developed by Melitz and Ottaviano (2008), in the next section I develop an appropriately modified (open economy) version in which I analyse the export versus FDI decision of heterogeneous firms and thereby derive the alternative sorting. The paper then ends with some conclusions in the last section.

\section{$2 \quad$ Model}

By incorporating the firm's (additional) possibility to serve a foreign market through foreign direct investment in this section I extend and appropriately adjust the monopolistic competition model with heterogeneous firms and quadratic consumer preferences developed by Melitz and Ottaviano (2008). In this way the approach is similar to the work by Helpman, Melitz and Yeaple (2004), who extend the Melitz (2003) model with CES consumer preferences. To structurally set up the model the closed economy is considered first.

\subsection{Closed Economy}

A country exhibits the following consumption and production structures.

\subsubsection{Preferences and Demand}

The country is inhabited by $L$ consumers with identical preferences, each consumer endowed with one unit of labour. Because of consumer homogeneity it is sufficient to consider one representative consumer, whose (quadratic) preferences are defined over a homogeneous good chosen as a numeraire and a continuum of horizontally differentiated product varieties indexed by $i \in \Omega$ and whose corresponding utility function is quasi-linear according to Ottaviano, Tabuchi and Thisse (2002):

$$
U=q_{0}^{c}+\alpha \int_{i \in \Omega} q_{i}^{c} d i-\frac{1}{2} \gamma \int_{i \in \Omega}\left(q_{i}^{c}\right)^{2} d i-\frac{1}{2} \eta\left(\int_{i \in \Omega} q_{i}^{c} d i\right)^{2}
$$

with $q_{0}^{c}$ and $q_{i}^{c}$ as the individual consumption levels of the numeraire good and of each variety $i \in \Omega$ respectively and $\alpha, \eta$ and $\gamma>0$ as the function parameters, where $\gamma$ describes the degree of product differentiation between the varieties. In its limiting case $\gamma=0$ product varieties become perfectly homogeneous and substitutable, with the effect that consumers only care about the total quantity of goods consumed, $Q^{c}=\int_{i \in \Omega} q_{i}^{c} d i$, not about the specific variety. This latter effect is only present if $\gamma$ is strictly positive. The parameters $\alpha$ and $\eta$ however describe the substitution pattern between the numeraire good and the differentiated varieties: An increase in $\alpha$ and a decrease in $\eta$ shift out the demand for the differentiated variety relative to the numeraire. Since the marginal utilities for all goods are bounded - that is, a positive and finite choke price for the goods exists the consumer may not has a positive demand for every good. By assumption the numeraire good is always consumed $\left(q_{0}^{c}>0\right)$, thereby absorbing all income effects.

The representative consumer maximizes utility over the set of feasible consumption allocations, represented by the individual budget constraint $q_{0}^{c}+\int_{i \in \Omega} p_{i} q_{i}^{c} d i=w$ with $p_{i}$ as the price of the differentiated variety $i \in \Omega$ and $w$ as the unit wage (price of the numeraire good normalized to one), which results in the following linear inverse demand for variety $i$ :

$$
p_{i}=\alpha-\gamma q_{i}^{c}-\eta Q^{c}
$$

whenever $q_{i}^{c}>0$; therefore, the subset of varieties that are in fact consumed is denoted by $\Omega^{*}=$ $\left\{i: q_{i}^{c}>0\right\} \subset \Omega$ with $N$ as the measure of varieties in $\Omega^{*}$. Aggregating over the $L$ homogeneous consumers and using the fact that $Q^{c}=\frac{N(\alpha-\bar{p})}{\gamma+\eta N}$ with $\bar{p}=\frac{1}{N} \int_{i \in \Omega} p_{i} d i$ as the average price of the varieties the country-wide demand for variety $i$ is given by

$$
q_{i}=\frac{\alpha L}{\gamma+\eta N}-\frac{L}{\gamma} p_{i}+\frac{\eta N}{\gamma+\eta N} \frac{L}{\gamma} \bar{p} \quad \forall i \in \Omega^{*} .
$$


For a price below the choke price $p_{\max }$ aggregate demand for variety $i$ is positive and the variety therefore part of the consumption set $\Omega^{*}$ :

$$
p_{i} \leq \frac{\alpha \gamma}{\gamma+\eta N}+\frac{\eta N}{\gamma+\eta N} \bar{p}=p_{\max }
$$

With equation (2) the price bound $p_{\max }$ can then be specified: $p_{\max } \leq \alpha$. The price elasticity of demand for variety $i$ is computed as $\varepsilon_{i} \equiv-\left(\partial q_{i} / \partial p_{i}\right)\left(p_{i} / q_{i}\right)=(1-\eta /(\gamma+\eta N))\left[p_{\max } / p_{i}-1\right]^{-1}$ and varies, in contrast to the case of a CES demand, with the price and the number of competitors: A lower average price $\bar{p}$ (a higher number of competing varieties $N$ ) ensures a decrease in the price threshold $p_{\max }$ (a decrease in the price threshold $p_{\max }$ and an increase in the first term of the elasticity expression) and therefore an increase in the price elasticity of demand $\varepsilon_{i}$ at any given price $p_{i}$; a situation contextually identified with a higher degree of competition (according to Melitz and Ottaviano (2008) a "tougher" competitive environment).

\subsubsection{Production and Supply}

The supply side in the country is characterized by monopolistic competition with a large number of small firms, each producing a horizontally differentiated product variety $i \in \Omega^{*}$, which is imperfectly substitutable with any other variety $i^{\prime} \in \Omega^{*}$ and $i^{\prime} \neq i$. Firms have to bear costs to enter the economy due to the conducting of research and development in order to create a competitive differentiated product variety and building up a production process, in which labour is the only factor of production. The production technology is identical across firms, but these are heterogeneous in their levels of productivity. So a unit variable cost of production for a firm with productivity $\varphi$ is denoted by $c(\varphi)=\frac{w}{\varphi}$. Formally, the productivity assignment to firms is depicted by a draw from a common and known distribution $G(\varphi)$ with support on $(0, \infty)$. Contextually, firms get to know their productivity and therefore learn about their production cost level only after entering the economy and making the irreversible start-up investment $f_{E}>0$ in form of paying sunk entry costs (measured in labour units). From the group of entrants only the firms that are able to cover their marginal costs survive and produce in the economy; all other firms exit. However, the surviving firms follow the objective of profit maximization, being in a situation in which, on the one hand, they have monopolistic power in producing and supplying the differentiated product variety, so using the residual demand function given by equation (3) in their optimization problem, and, on the other hand, they are encompassed by a continuum of firms (competitors), so taking the average price level $\bar{p}$ and the number of firms $N$ as given in their optimization problem (competitive environment).

Since it is symmetric across varieties produced by heterogeneous firms, instead of using variety indices the profit maximization problem can be formulated solely in terms of productivity levels (neglecting the sunk entry costs):

$$
\max _{p(\varphi)}(p(\varphi)-c(\varphi)) q(\varphi)
$$

The firm's optimal price $p(\varphi)$ is then determined by

$$
q(\varphi)=\frac{L}{\gamma}(p(\varphi)-c(\varphi))
$$

and bounded by the zero-demand price threshold $p_{\max }$ given by equation (4); thus in the case of a charged price $p(\varphi)$ above the upper limit $p_{\max }$ the respective firm exits the economy. $\varphi_{E}^{*}$ hence denotes the productivity level of the firm (called marginal firm) for which the following holds: $p\left(\varphi_{E}^{*}\right)=p_{\max }$, i.e. for which a price is chosen that drives the demand level down to zero. The assumption $\varphi_{E}^{*}>0$ ensures the factual exit of firms with productivity draws smaller than $\varphi_{E}^{*}$.

The profit-maximizing price can be expressed in terms of the choke price $p_{\max }$,

$$
p(\varphi)=\frac{1}{2}\left(p_{\max }+c(\varphi)\right)
$$


and the marginal firm (the one with the lowest possible productivity level in the economy) satisfies the condition $p\left(\varphi_{E}^{*}\right)=p_{\max }=c\left(\varphi_{E}^{*}\right)=\frac{w}{\varphi_{E}^{*}}$, realizing zero profits because of the equality of the (profit-maximizing) price and the variable costs and making it indifferent between remaining in the economy or exiting it. The economy-wide choke price determines firm-specific variables like the mark-up $\mu(\varphi)$, quantity $q(\varphi)$, revenue $r(\varphi)$ and profits $\pi(\varphi)$ as follows:

$$
\begin{gathered}
\mu(\varphi)=\frac{1}{2}\left(p_{\max }-c(\varphi)\right) \quad \text { and } \quad q(\varphi)=\frac{L}{2 \gamma}\left(p_{\max }-c(\varphi)\right), \\
r(\varphi)=\frac{L}{4 \gamma}\left(p_{\max }^{2}-c(\varphi)^{2}\right) \quad \text { and } \quad \pi(\varphi)=\frac{L}{4 \gamma}\left(p_{\max }-c(\varphi)\right)^{2} .
\end{gathered}
$$

All in all firms with a higher productivity charge lower prices (facing a less elastic part of the demand curve) and are able to realize both higher mark-ups and higher revenues than lower-productivity firms because of their cost and quantity of sales advantage; so these firms do not pass on all of the cost differential/productivity gain to consumers in form of lower prices, since a part of it is retained as higher mark-ups. Consequently these higher-productivity firms earn higher profits in the delineated monopolistic competition environment.

\subsection{Open Economy}

Now two countries $i$ and $j(i \neq j)$ are considered, both of the type described above (i.e. with identical consumer preferences across individuals and identical production technologies across firms within each country). Firms obtain a new entrepreneurial option in this setting: Besides only serving the economy they are located in (home country) firms now have the possibility to cross borders and extend their activity to the foreign country by exporting products to (operation mode denoted by $X$ ) or investing in its market (operation mode denoted by $F$ ). Along these alternatives for action three mutually exclusive types of firms can be distinguished, depending on their production and sales location: domestic firms, exporters and multinational enterprises.

To set the stage for the analysis and the fundamental rationale of choosing different operation modes (i.e. proximity-concentration trade-off) it is assumed that each firm type faces type-specific costs. Considering country $i$ as the representative enterprise base (e.g. location of its unique headquarters) with exports iceberg transport costs (including tariffs) $\tau^{i j}>1$ for goods traded from the (source) country $i$ to the (destination) country $j$ arise in addition to fixed costs $f_{X}>0$ regarding the separation of the headquarters and the sales location (measured in labour units), which requires some (financial) effort to arrange and coordinate marketing, distribution, logistics etc. in the sales market being locally distant relative to the headquarters as the source of these provided services. With FDI undertaken in country $j$ not only these fixed costs $f_{X}>0$ are relevant for the representative firm, but some further fixed costs $f_{I}>0$ regarding the separation of the headquarters and the production location (measured in labour units), which requires some (financial) effort to construct (additional) production facilities in a foreign country, to equip them with (physical and human) capital and to communicate between the headquarters and its implementation unit over the

distant. The description of the cost side of the distinct international operations of firms illustrates the fact that while exporting is associated with high variable costs, multinationalization generates high fixed costs and firms have to weigh both possibilities in the light of their objective of profit maximization.

\subsubsection{Preferences and Demand}

The population in each country is immobile across countries (the country-specific market size unchanged over time (segmented markets)) and therefore the individual and aggregate product variety demand in the open-economy setting is country-stationary and accordingly indexed. Everything else is unchanged compared to the closed-economy setting, only replicated for each of the two countries; especially, it is assumed that the utility function parameters $(\alpha$ and $\eta)$ are the same across countries. 


\subsubsection{Production and Supply}

The representative firm with some productivity $\varphi$ located in country $i$ makes the decision about its activities based on the maximization of its overall profits, i.e. the sum of profits from domestic and foreign operations. Since these are independent of each other (no links or interactions assumed), separable and linearly additive in the optimization objective, it is possible and appropriate to split up the firm's decision-making into three optimization problems: Regarding domestic sales, denoted by $q_{D}^{i}(\varphi)$, the firm solves

$$
\max _{p^{i}(\varphi)} \pi_{D}^{i}(\varphi)=\left(p^{i}(\varphi)-c^{i}(\varphi)\right) q_{D}^{i}(\varphi)
$$

with $p^{i}(\varphi)$ as the price of the variety produced by the representative firm with productivity $\varphi$ in country $i$ and $c^{i}(\varphi)$ as its unit variable costs of production. The optimization problem regarding firm activities respectively sales abroad (i.e. in country $j$ ), denoted by $q_{M}^{i j}(\varphi)$, is given by

$$
\max _{p_{M}^{j}(\varphi)} \pi_{M}^{i j}(\varphi)=\left(p_{M}^{j}(\varphi)-c^{*}(\varphi)\right) q_{M}^{i j}(\varphi)
$$

with $M \in\{X, F\}$ (mode of operation) and the unit variable costs of production as

$$
c^{*}(\varphi)=\left\{\begin{array}{lll}
\tau^{i j} c^{i}(\varphi) & \text { for } & M=X \\
c^{j}(\varphi) & \text { for } & M=F
\end{array},\right.
$$

while $p_{M}^{j}(\varphi)$ denotes the price of the respective (via exporting or foreign affiliates provided) variety in country $j, \tau^{i j}$ the transport costs for goods traded from country $i$ to country $j$ and $c^{j}(\varphi)$ the unit variable costs of production in country $j$. The firm's optimal prices are then determined by

$$
q_{D}^{i}(\varphi)=\frac{L^{i}}{\gamma^{i}}\left(p^{i}(\varphi)-c^{i}(\varphi)\right)
$$

and

$$
q_{M}^{i j}(\varphi)=\frac{L^{j}}{\gamma^{j}}\left(p_{M}^{j}(\varphi)-c^{*}(\varphi)\right) \quad \text { with } M \in\{X, F\}
$$

whereas the firm applies the aggregate demand in the domestic country and in the destination country respectively. The profit-maximizing prices withal are bounded by the country-specific choke prices:

$$
p\left(\varphi_{E}^{m *}\right)=p_{\max }^{m}=\frac{1}{\gamma^{m}+\eta N^{m}}\left(\alpha \gamma^{m}+\eta N^{m} \bar{p}^{m}\right) \quad \text { for } m \in\{i, j\},
$$

determining the productivity level of the marginal firm in the respective economy $\left(\varphi_{E}^{i *}\right.$ and $\left.\varphi_{E}^{j *}\right)$, which is assumed to be strictly positive in both countries, implying that some firms in fact exit the economy.

The operating profits from each of the firm's activities can easily be derived by determining the optimal price and quantity:

1. For domestic sales:

$$
p^{i}(\varphi)=\frac{1}{2}\left(p_{\max }^{i}+c^{i}(\varphi)\right), \quad q_{D}^{i}(\varphi)=\frac{L^{i}}{2 \gamma^{i}}\left(p_{\max }^{i}-c^{i}(\varphi)\right) \quad \text { and } \quad \pi_{D}^{i}(\varphi)=\frac{L^{i}}{4 \gamma^{i}}\left(p_{\max }^{i}-c^{i}(\varphi)\right)^{2}
$$

2. For foreign sales:

$$
p_{M}^{j}(\varphi)=\frac{1}{2}\left(p_{\text {max }}^{j}+c^{*}(\varphi)\right), \quad q_{M}^{i j}(\varphi)=\frac{L^{j}}{2 \gamma^{j}}\left(p_{\text {max }}^{j}-c^{*}(\varphi)\right) \text { and } \pi_{M}^{i j}(\varphi)=\frac{L^{j}}{4 \gamma^{j}}\left(p_{\text {max }}^{j}-c^{*}(\varphi)\right)^{2}
$$

with $M \in\{X, F\}$. 


\subsubsection{Economy Equilibrium and Sorting}

Given the above expressions for the operating profits from the three entrepreneurial activities heterogeneous (i.e. productivity-varying) firms can be sorted regarding their cross-border (international) participation depending on productivity thresholds. In an interval between these thresholds it is for example more profitable to export than to undertake FDI given the variable (transportation) and fixed costs (vice versa for another interval) and firms with an assigned productivity in this interval therefore have strong incentives to become an exporter instead of a multinational enterprise. Taking the assignment of productivity levels to firms as given, i.e. the uncertainty of productivity draws is solved, each firm only enters the domestic market if it is at least able to cover the fixed entry $\operatorname{costs} f_{E}$ with its operational profits from domestic sales. The minimal productivity level in country $i$ for serving the domestic market (domestic sales threshold), ensuring the equality of operational profits and fixed entry costs and therefore being the level of the marginal firm, is given by ${ }^{9}$

$$
\varphi_{E}^{i}=\frac{w^{i}}{p_{\max }^{i}-2 \sqrt{\frac{f_{E} \gamma^{i}}{L^{i}}}} .
$$

Having a productivity level above the threshold $\varphi_{E}^{i}$ allows firms to stay in the market, to serve it and to take into account the (additional) possibility of international participation, establishing the domestic sales threshold as the lowest possible productivity level of existing firms. Any international activity is only profitable and therefore undertaken by firms if it at least covers with its operational profits the associated fixed costs. The minimal productivity levels in country $i$ for both activities, exporting to and multinationalization in country $j$, leading to exactly zero (total) profits out of the corresponding firm activities, are

$$
\varphi_{X}^{i j}=\frac{\tau^{i j} w^{i}}{p_{\max }^{j}-2 \sqrt{\frac{f_{X} \gamma^{j}}{L^{j}}}}
$$

for exports (export sales threshold) and

$$
\varphi_{F}^{i j}=\frac{w^{j}}{p_{\max }^{j}-2 \sqrt{\frac{\left(f_{X}+f_{I}\right) \gamma^{j}}{L^{j}}}}
$$

for FDI (FDI sales threshold). ${ }^{10} \mathrm{~A}$ comparative statics analysis of these three thresholds reveals the existence of a market-size and a cost effect: An increase in the market size of country $i$ respectively $j$ leads to a decrease in the respective threshold, by increasing profits for each level of productivity and thereby leading to a lower level needed to cover (unchanged) fixed costs, while an increase in the fixed or variable costs raises the respective threshold, by reducing profits for each level of productivity or leading to higher fixed costs coverage requirements, making the participation in the activity only profitable for higher-productivity firms and therefore more restrictive.

The following analysis now puts the thresholds in a relation. In order to state $\varphi_{E}^{i}<\varphi_{X}^{i j}$, as already implied, the (conditional) assumption

$$
\sqrt{L^{j}}\left(p_{\text {max }}^{j}-\tau^{i j} p_{\text {max }}^{i}\right)<2\left(\sqrt{\gamma^{j}} \sqrt{f_{X}}-\frac{\tau^{i j} \sqrt{L^{j}}}{\sqrt{L^{i}}} \sqrt{\gamma^{i}} \sqrt{f_{E}}\right)
$$

\footnotetext{
${ }^{9}$ The analysis in this section considers total instead of operational profits as it was done in the model by Melitz and Ottaviano (2008) - fixed costs not further assumed to be sunk, but part of the firms' calculus - leading to a minimal productivity level for domestic market activity strictly larger than the level of the marginal firm $\left(\varphi_{E}^{i *}=w^{i} / p_{\text {max }}^{i}\right)$.

${ }^{10}$ Two assumptions are formulated and required to hold to ensure positive and thereby contextually interpretable values for the three thresholds:

and

$$
2 \sqrt{\gamma^{i}} \sqrt{f_{E}}<p_{\max }^{i} \sqrt{L^{i}}
$$$$
2 \sqrt{\gamma^{j}} \sqrt{f_{X}+f_{I}}<p_{\max }^{j} \sqrt{L^{j}}
$$ 
has to hold, which ensures that all firms profitably exporting also serve the domestic market. A larger market size of the destination country of exports $j$ counteracts the termed relation as it indicates larger sales volumes for exports and insures thereby for lower-productivity firms an easier coverage of the undertaken (financial) efforts to export to this country, so decreasing the productivity level needed for a profitable exporting. For the standard assumption of symmetric countries $i$ and $j$ inequality (17) reduces to

$$
p_{\max } \sqrt{L}\left(1-\tau^{i j}\right)<2 \sqrt{\gamma}\left(\sqrt{f_{X}}-\tau^{i j} \sqrt{f_{E}}\right)
$$

and illustrates that the relation is always obtained if the fixed costs of exporting are sufficiently high, i.e. $f_{X}>\left(\tau^{i j}\right)^{2} f_{E}$. In general inequality (17) can also be rewritten as

$$
\tau^{i j}>\frac{p_{\max }^{j} \sqrt{L^{j}}-2 \sqrt{\gamma^{j}} \sqrt{f_{X}}}{p_{\max }^{i} \sqrt{L^{j}}-2 \sqrt{\gamma^{i}} \frac{\sqrt{L^{j}}}{\sqrt{L^{i}}} \sqrt{f_{E}}},
$$

representing the requirement of sufficiently high variable costs of exporting to make sure that exporters also serve the domestic market (cf. comparative statics analysis). The cost threshold is determined by the adjusted (country-specific) choke prices, the adjusted fixed costs of exporting and the adjusted fixed costs of market entry.

To replicate the ordering induced by the conventional sorting, $\varphi_{X}^{i j}<\varphi_{F}^{i j}$, it must be assumed that

$$
p_{\text {max }}^{j} \sqrt{L^{j}}\left(1-z^{i j}\right)<2 \sqrt{\gamma^{j}}\left(\sqrt{f_{X}+f_{I}}-z^{i j} \sqrt{f_{X}}\right)
$$

holds, with $z^{i j} \equiv \frac{w^{j}}{\tau^{i j} w^{i}}<1$, which reduces for symmetric countries $i$ and $j$ to

$$
p_{\max } \sqrt{L}\left(\frac{\tau^{i j}-1}{\tau^{i j}}\right)<2 \sqrt{\gamma}\left(\sqrt{f_{X}+f_{I}}-\frac{1}{\tau^{i j}} \sqrt{f_{X}}\right)
$$

and illustrates that the relation is always obtained if the fixed costs of FDI are sufficiently high. The (conditional) assumption (19) sets an upper bound on the variable costs of exporting, since it can be written in the form

$$
\tau^{i j}<\frac{w^{j}}{w^{i}} \frac{p_{\max }^{j} \sqrt{L^{j}}-2 \sqrt{\gamma^{j}} \sqrt{f_{X}}}{p_{\max }^{j} \sqrt{L^{j}}-2 \sqrt{\gamma^{j}} \sqrt{f_{X}+f_{I}}}
$$

where in addition to the country wages the adjusted choke price of the destination country $j$, the adjusted fixed costs of exporting and the adjusted fixed costs of FDI define the bound.

Besides the zero-profit thresholds another group of relevant productivity values exists. To compute possible productivity thresholds for which profits from exporting and FDI are equal and which therefore indicate for an infinitesimal change in productivity a change in the chosen mode of international activity, depending on which mode yields higher profits, the expressions for total profits from export and FDI sales, $\Pi_{M}^{i j}$ for $M \in\{X, F\}$, are set equal to each other, yielding the following thresholds:

$$
\varphi_{1,2}^{i j}=\frac{p_{\max }^{j} \pm \sqrt{\left(p_{\max }^{j}\right)^{2}-\frac{f_{I} 4 \gamma^{j}}{L^{j} \omega_{(-)}^{i j}} \omega_{(+)}^{i j}}}{\frac{f_{I} 4 \gamma^{j}}{L^{j} \omega_{(-)}^{i j}}}
$$

with $0<\tau^{i j} w^{i}-w^{j} \equiv \omega_{(-)}^{i j}<\omega_{(+)}^{i j} \equiv \tau^{i j} w^{i}+w^{j}$, whereby the existence of two contextually applicable solutions is only ensured if the following assumption holds:

$$
2 \sqrt{\gamma^{j}} \sqrt{f_{I}} \sqrt{\frac{\omega_{(+)}^{i j}}{\omega_{(-)}^{i j}}}<p_{\max }^{j} \sqrt{L^{j}} .
$$


The relation between the FDI sales threshold and the lower value of the profit functions intersections $\varphi_{F}^{i j}<\varphi_{1}^{i j}$ requires

$$
2 p_{\max }^{j} \Psi-\omega_{(+)}^{i j}<\frac{4 \gamma^{j} f_{I}}{L^{j} \omega_{(-)}^{i j}} \Psi^{2}
$$

with $\Psi \equiv \frac{w^{j} \sqrt{L^{j}}}{p_{\text {max }}^{j} \sqrt{L^{j}}-2 \sqrt{\gamma^{j}} \sqrt{f_{X}+f_{I}}}$. A sufficient (conditional) assumption for inequality (23) is given by

$$
\tau^{i j}<\frac{w^{j}}{w^{i}} \frac{\sqrt{\gamma^{j}} f_{I}}{\left(1-z^{i j}\right) \sqrt{f_{X}+f_{I}}} \frac{1}{p_{\max }^{j} \sqrt{L^{j}}-2 \sqrt{\gamma^{j}} \sqrt{f_{X}+f_{I}}},
$$

which sets a further upper bound on the variable costs of exporting, with the adjusted choke price of country $j$, the adjusted additional fixed costs of FDI and the adjusted fixed costs of FDI as its arguments. (A3)

Summarizing, under the condition that $\varphi_{E}^{i}>0$ and the set of (conditional) assumptions (A1)-

$$
\begin{gathered}
2 \sqrt{\gamma^{j}} \sqrt{f_{I}} \sqrt{\frac{\omega_{(+)}^{i j}}{\omega_{(-)}^{i j}}<p_{\text {max }}^{j} \sqrt{L^{j}}} \\
\tau^{i j}>\max \left\{\frac{p_{\max }^{j} \sqrt{L^{j}}-2 \sqrt{\gamma^{j}} \sqrt{f_{X}}}{p_{\text {max }}^{i} \sqrt{L^{j}}-2 \sqrt{\gamma^{i}} \frac{\sqrt{L^{j}}}{\sqrt{L^{i}}} \sqrt{f_{E}}}, 1\right\} \\
\tau^{i j}<\frac{w^{j}}{w^{i}} \frac{1}{p_{\text {max }}^{j} \sqrt{L^{j}}-2 \sqrt{\gamma^{j}} \sqrt{f_{X}+f_{I}}} \min \left\{\frac{\sqrt{\gamma^{j}} f_{I}}{\left(1-z^{i j}\right) \sqrt{f_{X}+f_{I}}}, p_{\text {max }}^{j} \sqrt{L^{j}}-2 \sqrt{\gamma^{j}} \sqrt{f_{X}}\right\}
\end{gathered}
$$

hold the following ranking of productivity thresholds (regarding a fixed (destination) country $j$ ) can be established as a result of the analysis (Figure 1):

$$
0<\varphi_{E}^{i}<\varphi_{X}^{i j}<\varphi_{F}^{i j}<\varphi_{1}^{i j}<\varphi_{2}^{i j}
$$

Thereby the threshold $\varphi_{F}^{i j}$ is irrelevant or only hypothetical for the sorting of firms, since it represents indeed the productivity value which ensures for corresponding higher values strictly positive profits from multinationalization, but it does not make any statement about the relation of those profits to the profits from exporting (in contrast to $\varphi_{1}^{i j}$ and $\varphi_{2}^{i j}$ ), which gets profitable for an even lower productivity value. With $\varphi_{X}^{i j}<\varphi_{F}^{i j}<\varphi_{1}^{i j}$ and monotonic profit functions it is clear that firms with a productivity level in the interval $\left[\varphi_{X}^{i j}, \varphi_{1}^{i j}\right]$ prefer exporting over multinationalization and are therefore all exporters, both to the left and the right of the threshold $\varphi_{F}^{i j}$ (cf. Figure 1), insofar not indicating any switch in firm behaviour.

The sequence of productivity thresholds given by inequality (25) implies the following type of allocation of (international) operation modes across firm productivity (Figure 2): The least productive firms, whose productivity level is smaller than $\varphi_{E}^{i}$, exit the economy, while low-productivity firms with a productivity level between $\varphi_{E}^{i}$ and $\varphi_{X}^{i j}$ only serve the domestic market and are therefore called domestic firms. All firms with higher productivity levels add to their portfolio foreign market activities in one of two conceivable forms (exporting or foreign direct investment). Those firms with intermediate productivity levels, i.e. between $\varphi_{X}^{i j}$ and $\varphi_{1}^{i j}\left(\equiv \varphi_{X, F}^{i j}\right)$, export product varieties to a foreign market (exporters) and high-productivity ones with a productivity value between $\varphi_{1}^{i j}$ and $\varphi_{2}^{i j}\left(\equiv \varphi_{F, X}^{i j}\right)$ serve the foreign market by undertaking foreign direct investment, i.e. establishing affiliates in the foreign market (multinational enterprises). Finally the highest productive firms, i.e. those with a level above $\varphi_{2}^{i j}$, again decide to export their products to the foreign market (exporters). Thereby I derive a type of sorting which I want to call sandwich sorting that differs from 


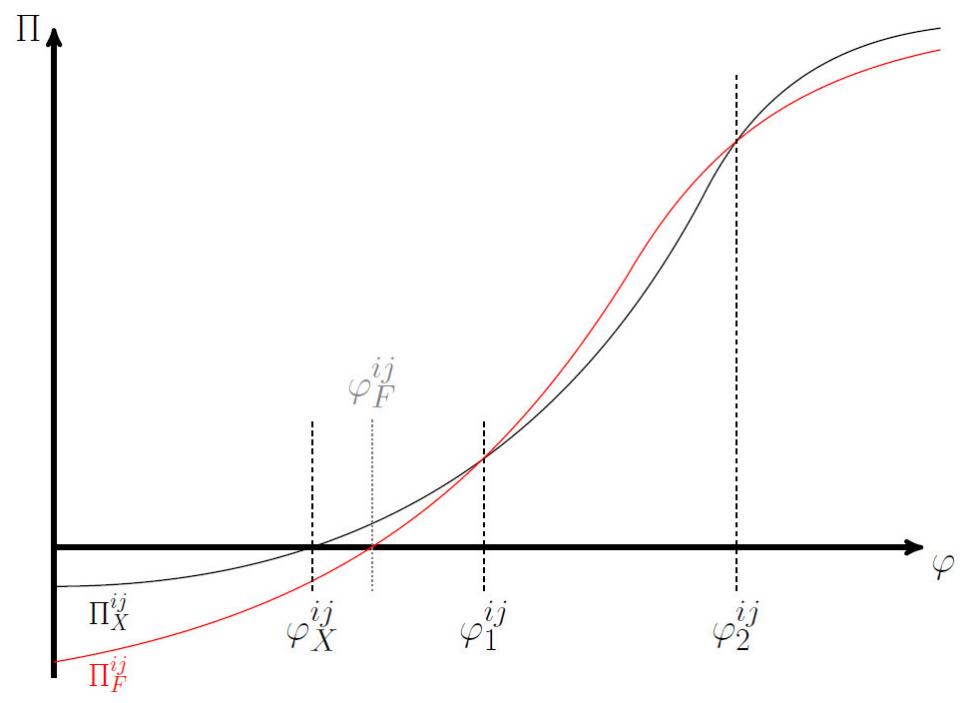

Figure 1: Stylized representation of the export and FDI profit functions and the productivity thresholds

the one developed in the literature ${ }^{11}$, since at the top end of the interval of productivity values the structure is reversed: Up to the threshold $\varphi_{2}^{i j}$ the conventional sorting, previously described by Helpman, Melitz and Yeaple (2004) in a setting with CES preferences, is replicated. With an increasing productivity level firms charge lower prices, distribute higher volumes of sales and are also able to realize higher mark-ups and profits. While low-productivity firms are only in the position to serve the foreign market via exports because of their relatively low fixed costs and relatively low (total) variable costs due to limited sales volumes (concentration more important than proximity), higher-productivity firms would suffer from high (total) variable costs due to high sales volumes associated with exporting and are therefore incentivized to shift to foreign direct investments bearing relatively high fixed costs while saving variable costs (proximity more important than concentration) and thereby optimizing their profits. These (profit-maximizing) choices of firms reflect their solution approach to the proximity-concentration trade-off. Importantly, given quadratic consumer

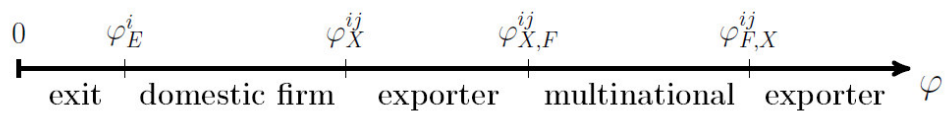

Figure 2: Type of allocation of (international) operation modes across firm productivity (sandwich sorting)

preferences the highest-productivity firms change their response to this trade-off by switching from FDI back to exports (cf. Figure 2). These firms with a sufficiently high productivity that charge low prices face a low-elasticity part of the demand curve for which any further decrease in prices leads only to a small increase in demand respectively sales and so the incentives for those firms to implement foreign direct investments with the aim to eliminate variable costs and to reduce prices in exchange for high fixed costs relatively diminishes respectively vanishes due to the low demand response to prices changes. Put differently, the loss in demand and operating profits due to exporting is smaller than the savings on fixed costs and this calculation induces those firms to switch from FDI to exporting. This constitutes the reversal of firm activity at high productivity

\footnotetext{
${ }^{11}$ Deviations from conventional sorting are theoretically also found in a general equilibrium Ricardian model with within-country and within-sector productivity homogeneity, see De Jesus Noguera and Pecchenino (2011), and in a firm-heterogeneity model with additional cross-country factor-price and market-size heterogeneity, thereby allowing for vertical investment motives of firms, see Head and Ries (2003).
} 
levels and leads to the so-called sandwich sorting.

Technically, the result arises because of the relative convexity of the export profit function (cf. Figure 1). According to Cargo (1965) a necessary and sufficient condition for this property is given by

$$
\frac{\Pi_{X}^{\prime \prime}}{\Pi_{X}^{\prime}} \geq \frac{\Pi_{F}^{\prime \prime}}{\Pi_{F}^{\prime}}
$$

with $\Pi_{M}^{\prime \prime}$ as the second derivative and $\Pi_{M}^{\prime}$ as the first derivative of the total profit function for $M \in\{X, F\}$. Equivalently rearranged the condition reduces to the requirement that $\tau^{i j} w^{i} \geq w^{j}$ or $\omega_{(-)}^{i j} \geq 0$ holds, which is fulfilled for the present analysis. For the case of symmetric countries with identical wages the formulation of the variable costs of exporting in terms of iceberg transport $\operatorname{costs}\left(\tau^{i j}>1\right)$ is enough to generate the relative convexity of the export profit function and hence the sandwich sorting.

The analysis and its outcome are related to and consistent with the work by Mrázová and Neary (2011), who study in general a firm's choice between different modes of (international) operation (applicable to the choice between exporting and FDI) for different types of demand and supply conditions, depending on firm heterogeneity (selection effects). Based on the concept of supermodularity of the objective function (i.e. the (maximum operating) profits function $\pi(t, c)$ ) they are able to make statements about the preferred practices of firms. Regarding their behaviour in serving foreign markets Mrázová and Neary (2011) can fundamentally derive the result that for the case of a supermodular profit function (supermodular in its both arguments, i.e. in $t$ (access/transport costs/tariffs) and $c$ (marginal production costs)) higher-cost (less productive) firms will select into exports, while lower-cost (more productive) firms will select into FDI, for all admissible fixed costs. To determine firm selection it is therefore necessary and sufficient to derive conditions for the supermodularity of $\pi(t, c)$. One essential condition is given by the characteristics of the applied demand function, its elasticity $(\varepsilon)$ and its curvature $(\rho)$ : Supermodularity of $\pi(t, c)$ is satisfied if and only if $\varepsilon+\rho>3$. So a superconvex demand (i.e. some demand with a representative function being more convex than that of the CES demand) always implies supermodularity and therefore the case that lower-cost firms choose FDI. Submodularity and thus the breaking up of the conventional sorting is more likely when demand is less elastic and more concave. For linear, i.e. subconvex, demand (with $\rho=0$ and the condition for supermodularity hence: $\varepsilon>3$ ), as considered in the present paper, the price elasticity is monotonically decreasing in the output and the profit function is thus supermodular for high-cost firms and submodular for low-cost firms. For those gains to FDI are relatively small and they choose exporting instead of FDI to serve the foreign market (reverse selection effects), which is consistent with the result generated in the present paper, calling it sandwich sorting.

With the empirical evidence mentioned in the introduction it is possible to find some empirical indication or support for sandwich sorting. Two forms of international firm activities, in particular investment and services trade, reveal some differences to conventional sorting, which is widely confirmed in the literature (cf. note 5), in favour of the derived alternative sorting type. Therefore the empirical finding about international firm behaviour and operation modes gets more mixed and the model in this paper is able to provide some explanation for this fact.

\section{Conclusion}

This paper investigates the robustness of the conventional sorting of heterogeneous and crossborder active firms. According to Helpman, Melitz and Yeaple (2004), the high-productivity firms are engaged in FDI, while firms with intermediate productivity values export and low-productivity firms only serve the domestic market. By substituting the applied CES preferences with quadratic preferences, yielding linear demand, this sorting changes in the top range of productivity values. The highest-productivity firms do not undertake FDI to serve the foreign market, but export their products again. A sandwich sorting of firms is theoretically derived and can empirically be supported by investment and services trade pattern. 


\section{References}

(1) Antràs, P. and S. R. Yeaple (2014), Multinational Firms and the Structures of International Trade. In: G. Gopinath, E. Helpman and K. Rogoff (eds.). Handbook of International Economics Vol. 4 (pp. 55-130), Amsterdam: Elsevier.

(2) Arnold, J. M. and K. Hussinger (2010). Exports versus FDI in German Manufacturing: Firm Performance and Participation in International Markets, Review of International Economics 18(4), pp. 595-606.

(3) Baltagi, B. H., P. Egger and M. Pfaffermayr (2007). Estimating Models of Complex FDI: Are There Third-Country Effects?, Journal of Econometrics 140(1), pp. 260-281.

(4) Barron, J. M., J. R. Umbeck and G. R. Waddell (2008). Consumer and Competitor Reactions: Evidence from a Field Experiment, International Journal of Industrial Organization 26(2), pp. 517-531.

(5) Bernard, A. B. and J. B. Jensen (1995). Exporters, Jobs, and Wages in U.S. Manufacturing: 1976-1987, Brookings Papers on Economic Activity. Microeconomics, pp. 67-119.

(6) Bernard, A. B. and J. Wagner (1997). Exports and Success in German Manufacturing, Review of World Economics 133(1), pp. 134-157.

(7) Bernard, A. B., J. B. Jensen, S. J. Redding and P. K. Schott (2007). Firms in International Trade, Journal of Economic Perspectives 21(3), pp. 105-130.

(8) Bhattacharya, R., I. Patnaik and A. Shah (2012). Export versus FDI in Services, The World Economy 35(1), pp. 61-78.

(9) Brainard, S. L. (1997). An Empirical Assessment of the Proximity-Concentration Trade-Off Between Multinational Sales and Trade, American Economic Review 87(4), pp. 520-544.

(10) Campbell, J. R., H. A. Hopenhayn (2005). Market Size Matters, Journal of Industrial Economics 53(1), pp. 1-25.

(11) Cargo, G. T. (1965). Comparable Means and Generalized Convexity, Journal of Mathematical Analysis and Applications 12(3), pp. 387-392.

(12) Caves, R. E. (2007). Multinational Enterprise and Economic Analysis, Third Edition, Cambridge University Press, Cambridge.

(13) De Jesus Noguera, J. and R. A. Pecchenino (2011). FDI versus Exports in a General Equilibrium Ricardian Model, Economic Record 87(278), pp. 438-448.

(14) De Loecker, J. and F. Warzynski (2012). Markups and Firm-Level Export Status, American Economic Review 102(6), pp. 2437-2471.

(15) De Loecker, J., P. K. Goldberg, A. K. Khandelwal and N. Pavcnik (2016). Prices, Markups and Trade Reform, Econometrica, forthcoming.

(16) Doms, M. E. and J. B. Jensen (1998), Comparing Wages, Skills, and Productivity between Domestically and Foreign-Owned Manufacturing Establishments in the United States. In: R. E. Baldwin, R. E. Lipsey and J. D. Richards (eds.). Geography and Ownership as Bases for Economic Accounting (pp. 235-258), Chicago: University of Chicago Press.

(17) Ekholm, K., R. Forslid and J. R. Markusen (2007). Export-Platform Foreign Direct Investment, Journal of the European Economic Association 5(4), pp. 776-795. 
(18) Engel, D. and V. Procher (2012). Export, FDI and Firm Productivity, Applied Economics 44(15), pp. 1931-1940.

(19) Foster-McGregor, N., A. Isaksson and F. Kaulich (2014). Outward Foreign Direct Investment, Exporting and Firm-Level Performance in Sub-Saharan Africa, Journal of Development Studies 50(2), pp. 244-257.

(20) Francois, J. and B. Hoekman (2010). Services Trade and Policy, Journal of Economic Literature 48(3), pp. 642-692.

(21) Girma, S., R. Kneller and M. Pisu (2005). Exports versus FDI: An Empirical Test, Review of World Economics 141(2), pp. 193-218.

(22) Greenaway, D. and R. Kneller (2007). Firm Heterogeneity, Exporting and Foreign Direct Investment, Economic Journal 117(517), pp. F134-F161.

(23) Grossman, G. M., E. Helpman and A. Szeidl (2006). Optimal Integration Strategies for the Multinational Firm, Journal of International Economics 70(1), pp. 216-238.

(24) Hanson, G. H., R. J. Mataloni and M. J. Slaughter (2005). Vertical Production Networks in Multinational Firms, Review of Economics and Statistics 87(4), pp. 664-678.

(25) Head, K. and J. Ries (2003). Heterogeneity and the FDI versus Export Decision of Japanese Manufacturers, Journal of the Japanese and International Economies 17(4), pp. 448-467.

(26) Helpman, E. (1984). A Simple Theory of International Trade with Multinational Corporations, Journal of Political Economy 92(3), pp. 451-471.

(27) Helpman, E., M. J. Melitz and S. R. Yeaple (2004). Export Versus FDI with Heterogeneous Firms, American Economic Review 94(1), pp. 300-316.

(28) Hummels, D., P. J. Klenow (2005). The Variety and Quality of a Nation's Exports, American Economic Review 95(3), pp. 704-723.

(29) Kimura, F. and K. Kiyota (2006). Exports, FDI, and Productivity: Dynamic Evidence from Japanese Firms, Review of World Economics 142(4), pp. 695-719.

(30) Markusen, J. R. (1984). Multinationals, Multi-Plant Economies, and the Gains from Trade, Journal of International Economics 16(3-4), pp. 205-226.

(31) Markusen, J. R. and A. J. Venables (2000). The Theory of Endowment, Intra-Industry and Multinational Trade, Journal of International Economics 52(2), pp. 209-234.

(32) Mayer, T. and G. I. P. Ottaviano (2008). The Happy Few: The Internationalisation of European Firms, New Facts based on Firm-level Evidence, Intereconomics 43(3), pp. 135148.

(33) Melitz, M. J. (2003). The Impact of Trade on Intra-Industry Reallocations and Aggregate Industry Productivity, Econometrica 71(6), pp. 1695-1725.

(34) Melitz, M. J. and G. I. P. Ottaviano (2008). Market Size, Trade, and Productivity, Review of Economic Studies 75(1), pp. 295-316.

(35) Motta, M. and G. Norman (1996). Does Economic Integration Cause Foreign Direct Investment?, International Economic Review 37(4), pp. 757-783.

(36) Mrázová, M. and P. Neary (2011). Selection Effects with Heterogeneous Firms, Oxford Discussion Paper. 
(37) Oberhofer, H., M. Pfaffermayr (2012). FDI versus Exports: Multiple Host Countries and Empirical Evidence, The World Economy 35(3), pp. 316-330.

(38) Ottaviano, G. I. P., T. Tabuchi and J.-F. Thisse (2002). Agglomeration and Trade Revisited, International Economic Review 43(2), pp. 409-436.

(39) Ramondo, N., V. Rappoport and K. Ruhl (2013). The Proximity-Concentration Tradeoff under Uncertainty, Review of Economic Studies 80(4), pp. 1582-1621.

(40) Spearot, A. C. (2012). Firm Heterogeneity, New Investment and Acquisitions, Journal of Industrial Economics 60(1), pp. 1-45.

(41) Tomiura, E. (2007). Foreign Outsourcing, Exporting, and FDI: A Productivity Comparison at the Firm Level, Journal of International Economics 72(1), pp. 113-127.

(42) Wagner, J. (2006). Exports, Foreign Direct Investment, and Productivity: Evidence from German Firm-Level Data, Applied Economics Letters 13(6), pp. 347-349.

(43) Wagner, J. (2014). Exports, Foreign Direct Investments and Productivity: Are Services Firms Different?, Service Industries Journal 34(1), pp. 24-37.

(44) Yeaple, S. R. (2003). The Complex Integration Strategies of Multinationals and Cross Country Dependencies in the Structure of Foreign Direct Investment, Journal of International Economics 60(2), pp. 293-314. 